Volume 8. No. 5, May 2020

International Journal of Emerging Trends in Engineering Research

Available Online at http://www.warse.org/IJETER/static/pdf/file/ijeter455852020.pdf

https://doi.org/10.30534/ijeter/2020/45852020

\title{
Green and Lean Industrial Engineering Practices in Selected Manufacturing Units in Andhra Pradesh: Statistical Analysis
}

\author{
Dr.A.M.Mahaboob Basha ${ }^{1}$, Dr.M.Rajaiah ${ }^{2}$, Dr.O.Vijayakumar ${ }^{3}$, Dr.Y.Haranath ${ }^{4}$, T.Srinivasulu ${ }^{5}$ \\ ${ }^{1}$ Department of Management Studies, Audisankara College of Engineering \& Technology, Gudur, \\ drbasha3@gmail.com \\ ${ }^{2}$ Department of Mathematics, Audisankara College of Engineering \& Technology, Gudur, \\ rajagopal1402@gmail.com \\ ${ }^{3}$ Department of Management Studies, Narayana Engineering College, Gudur, vijayakumar12121@ gmail.com \\ ${ }^{4}$ Department of freshman engineering, Audisankara College of Engineering \& Technology, Gudur, \\ haranath.yeddala@gmail.com \\ ${ }^{5}$ Department of freshman engineering, Audisankara College of Engineering \& Technology, Gudur, \\ creativesrinivasulu1987@gmail.com
}

\begin{abstract}
The aim of present research study was to identify the impact of green and lean industrial manufacturing concern. The research aims to study the significant factors of green engineering practices like: reduce environmental impact, reduce environmental waste through efficient use of resources, product life cycle and reducing the production of $\mathrm{Co} 2$ in the manufacturing units followed by the lean manufacturing aspects like: improve quality, reduce cost, increase flexibility, minimize lead time, reduce wastage of material, value stream mapping on the selected manufacturing units. The research has given primary importance to secondary data sources followed by primary data sources. The researcher is trying to extract the evidences from various articles and publications to the current research. Here, have taken the advantage of various models proposed by authors with their references to the current research. The researcher trying to check the optimization through robustness analysis with the help of correlation analysis. The model was validated through various case studies by judging the suitability to current research study. The major outcome of the research study revealed that the practices (green \& lean) in industrial manufacturing concern. The study reveals new factors which give competitive advantages in the competitive era. The green practices which enhance the operational efficiency, improve environment and operational financial performance
\end{abstract}

Key words: green, lean, best manufacturing practices, engineering, industrial, environmental sustainability.

\section{INTRODUCTION}

The environmental sustainability and to overcome the natural hazard on earth, need to implement green industrial manufacturing practices in the contemporary world of industrial engineering practices. The lean and green practices which are essential for environmental sustainability along with financial growth of the organization. The green industrial engineering practices influence on reduce environmental impact, reduce environmental waste through efficient use of resources, product life cycle and reducing the production of $\mathrm{Co} 2$ in the manufacturing units are essential for environmental sustainability followed by the lean manufacturing aspects like: improve quality, reduce cost, increase flexibility, minimize lead time, reduce wastage of material, value stream mapping on the selected manufacturing units are essential t0 strengthen the organization financially [1][2].The both green and lean manufacturing concerns play a significant role to develop/protect nation economically along with environmental sustainability. We need to design certain GI (Green Initiatives) and LI(Lean Initiatives) to implement in the organization. The following Figure 1 reveals the concept of Green and Lean Industrial engineering manufacturing practices.

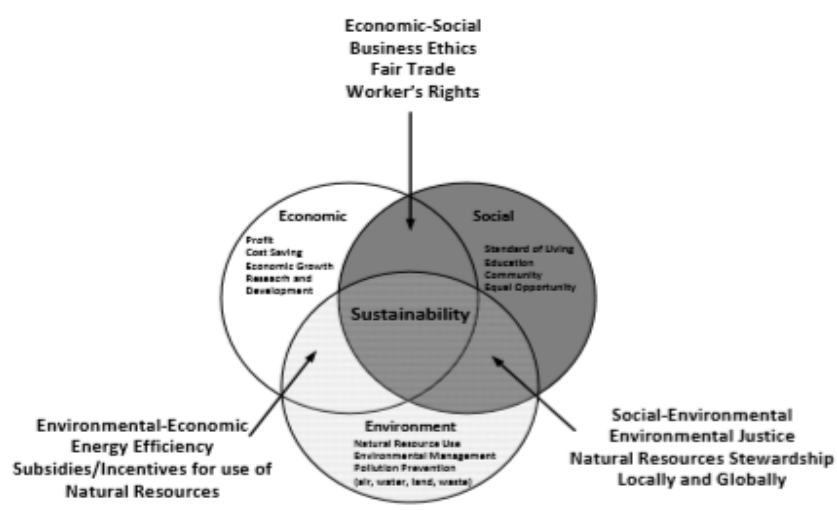

Figure 1: The three pillars of sustainability performance defined in [7]

\section{REVIEW OF LITERATURE}

There is a huge research GAP that, though many companies are coming forward to implement green and lean industrial manufacturing practices, industries do not reached to the expected level of green and lean manufacturing aspects in many countries, that is the reason why companies are getting failure to the expected output from the companies related to green and lean manufacturing aspects [3]. In this regard suggested that, manufacturing units need to strictly implement 
green objectives in the industries [4].The green practices in manufacturing concern include the reducing hazardous emissions; reduce the wastage of resources, recycling of wastage, implementing safety measurements and risk free measurements to overcome problems in the industrial manufacturing units [5]. In fact, there are some other researchers proved that pure green industrial manufacturing practices are not sufficient for economical sustainability of the organization [6]. The direction cum concentration at industrial production majorly concentrates on design, quality and cost reduction, the implementation of green practices in the manufacturing units many be burden to the industrial units, which many impact on quality of the manufacturing concern[8][9]. The green strategist and practitioners agreed that, the implementation of green and lean practices and balancing them in a systematic manner are both challenging aspects which impact on environmental sustainability and financial development of the organization[10][11][12]. The integration process, combining the green and lean practices may not be suitable and differ. Because, both were having different objectives, which are complement to each other. Achieving the object of both green and lean initiatives many not workout practically [13][14]. Continuing, few studies also witnessed that, both green and lean practices will shows the negative relationship with each other, but they may exist. In the case of green practices, the organizations striving for environmental sustainability where as lean practices include effectively implementation of quality control techniques [15][16].

\section{CONCEPTUAL FRAMEWORK}

A study being conducted by the author on the waste reduction policy and the overall performance of the cost and environmental sustainability on plastic supply recycling [18]. Proved a new concept how demolition methods used for civil structures. Applied sophisticated methods to overcome environmental pollution such as reduced air contamination and noise pollution [19]. The Figure 2 explains the basic characteristics of Green and Lean Industrial Engineering Practices.

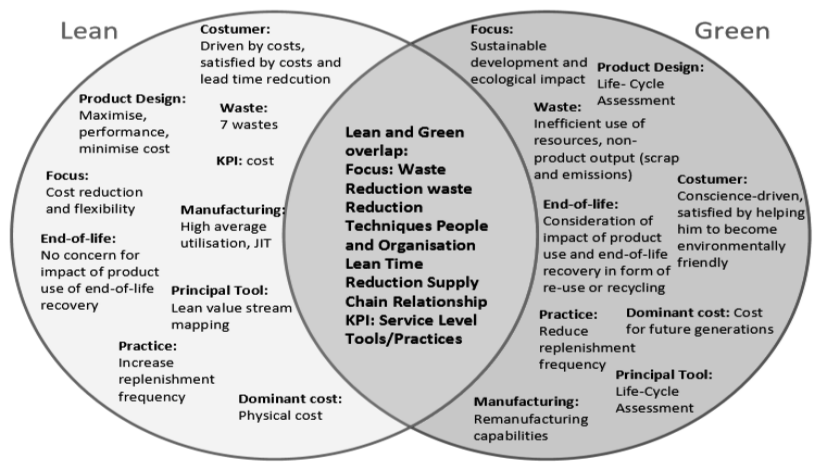

Figure 2: Lean and Green philosophies (Adapted from [17])

The green initiatives like: The environmental sustainability is the major concept behind Green initiatives along with this need to strengthen the organization economically viable. The
Green initiatives like: prevention of air, water and land pollution along with protecting society people from health hazards and reducing $\mathrm{Co}_{2}$ level in the air and avoiding earth disparity and actively taking social responsibility are the major aspects of green manufacturing [20]. In this regard organizations are redeveloping their products which will not create harm to the society and environment. The concept also called as environmentally conscious manufacturing can also be called as Green Manufacturing. The Green practices will protect the future generation by giving fresh air, water and resources also. Along with this the Lean practices also economically will strengthen the nation in many aspects. They include: application of time study and method study will possible to implement viable economic policies to strengthen the financial aspects of the organization. The following Figure 3 reveals the Green and Lean dynamic model which shows the systematic procedure.

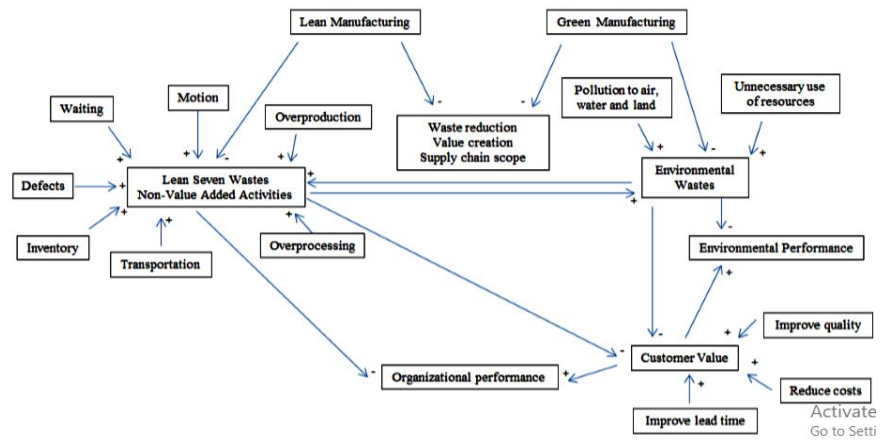

Figure 3: Lean and Green system dynamics model

There are three different manufacturing philosophies to reduce wastage to introduce green manufacturing. These approaches include pollution control, pollution prevention, production stewards. All these three measures are trying to introduce green measurements especially in the area of green practices in manufacturing areas [21]. The lean manufacturing include: reduce inventory and transportation cost, reduce wastage, over production, waiting time, defects in the manufacturing concern whereas green manufacturing include: pollution control, unnecessary usage of resources, avoid harmful practices to the society, create customer and employee value. The below Figure 4 proves the success factor model of Green and Lean industrial Engineering manufacturing Model.

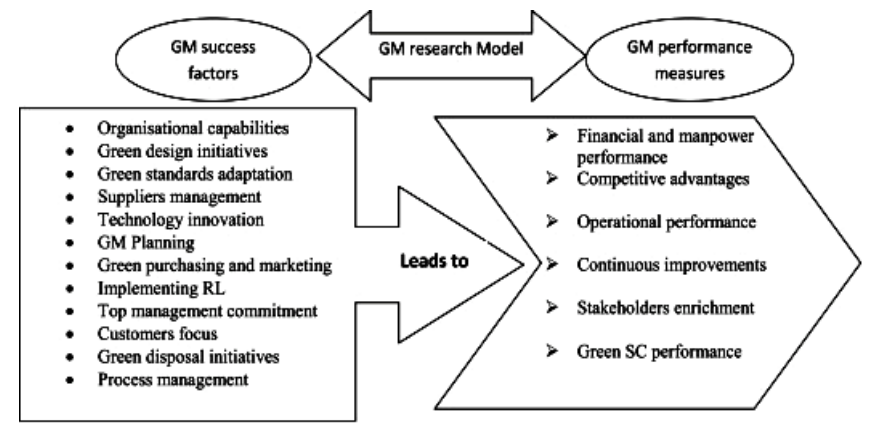

Figure 4: Lean and Green success factor model

There are certain green success factors which impact on and to implement green practices for environmental sustainability 
and remove hazardous and health issues to the employees, customers and public. They are: green design initiatives, green standard adoption, green technology innovation and adoption, green purchasing and marketing, customer focus related to health, society focus concerned to supply green products, employee focus related to health issues, green disposal initiatives and green manufacturing process are the major issues in the green manufacturing initiatives. The set of green initiatives leads to operational performance in manufacturing concern; competitive performance, financial performance, continuous improvements and stake holder's performance are the outcomes of green initiatives in the manufacturing units. In fact, the green practices plays a pivotal role for environmental sustainability which helps to give pollution free nation to the future generation, which is essential in the contemporary business world, where many pandemics are coming to ruin the human existence.

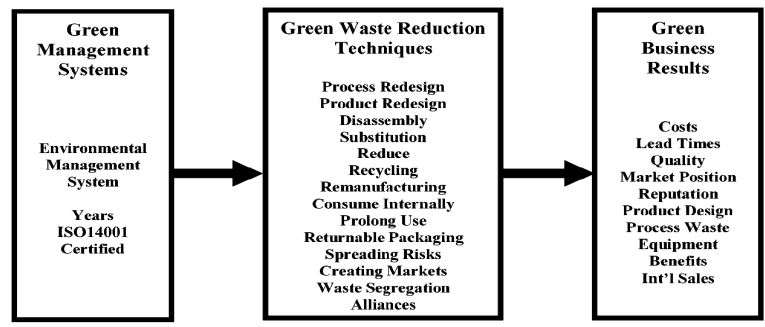

Figure 5: Green Management System: ISO 4001

From the above Figure 5 reveals the ISO model of green manufacturing system. The green management system ISO 14001 certified has designed certain green waste reduction techniques like: process redesign, product redesign, disassembly, substitution, reduce, recycling, remanufacturing, returnable packaging, waste segregation alliances are the best green waste reduction techniques, the green business results include costs of the manufacturing can be minimized, lead time can be minimized, quality of the production can be enhanced, market position can be stabilized, product and process design can be developed. The green manufacturing management system will give tremendous results for the betterment cum implementation of green and lean practices in the industrial manufacturing areas. The following Figure 6 reveals the historical aspects of Green practices in manufacturing.

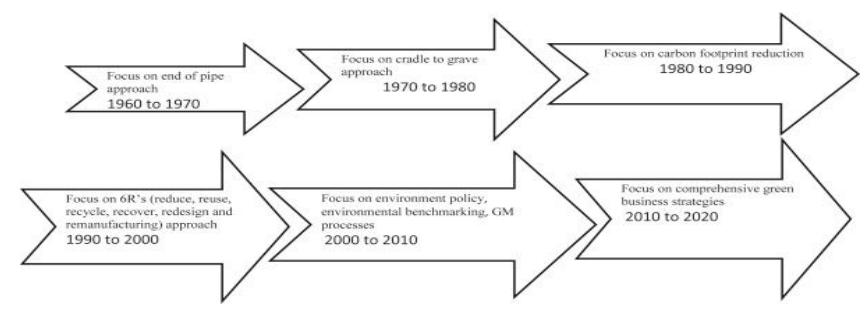

Figure 6: Evolution of Green Practices in manufacturing sector

In the historical perspective from 1960-70 pipe approach being followed in manufacturing industries followed by grave approach followed from 1970-1980 and carbon footprint reduction from 1980-90 and from 1990-2000 followed 6R's approach like: reduce, reuse, recycle, recover, redesign and remanufacturing approach has been followed by focus on environmental bench marking policy approach applied and now the greater importance has given to green manufacturing procedures from 2010-20 being applied.
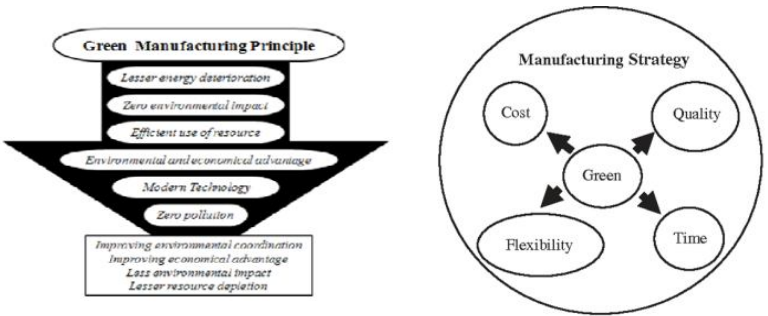

Figure 7: Green Manufacturing Principles and strategies

The Figure 7 reveals the green manufacturing principles like: lesser energy consumption and zero environmental impact efficient and maximum utilization of resources followed by implementation of modern technology zero pollution and improving environmental coordination, less environmental impact and lesser resource depletion are the major principles of green manufacturing principles. The green manufacturing strategies include minimizing cost, quality aspects and flexible over manufacturing and time are the major aspects.

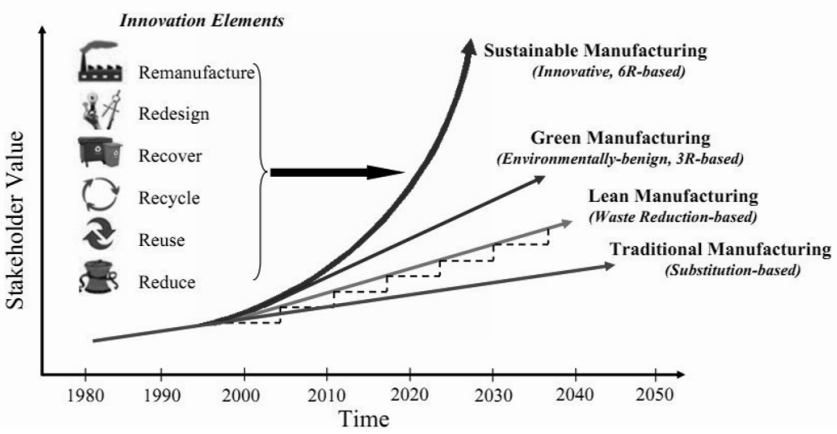

Figure 8: Evolution of sustainable manufacturing (Jawahir, 2008) [22]

The Figure 8 depicts Green and Lean manufacturing include 6R-based sustainable manufacturing which include: reduce, reuse, recycle, recover, redesign and remanufacturing [22]. The Green manufacturing majorly include: 3R- Model: Reduce, Reuse and Recycle. All these, are the essential philosophies of Green and Lean manufacturing practices in the aspects of environmental sustainability and strengthening organization financially sound.

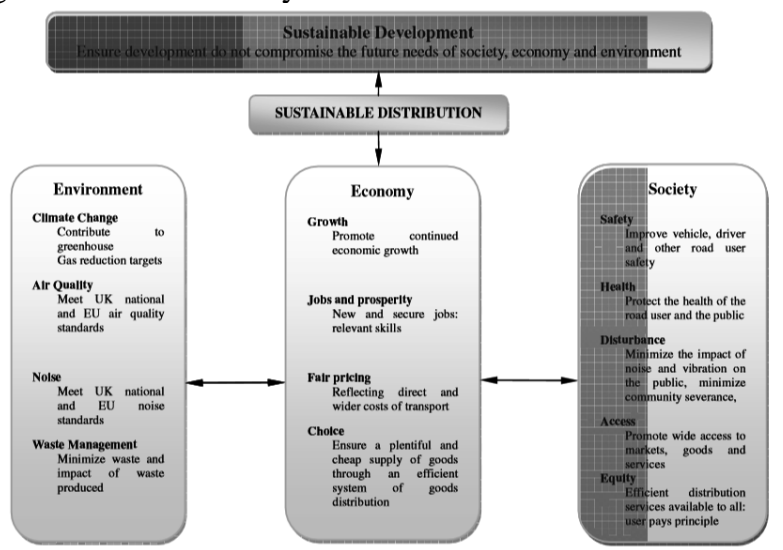

Figure 9: The Green Sustainable Distribution: A Strategy [23] The Figure 9 reveals sustainable distribution comprises of environment, economy and society. The environment: Air 
Quality, water Quality and to overcome land pollution along with waste management. The economic contribution to the nation in terms of GDP acceleration and employment creation and can avoid artificial demand of the products and can minimize the cost of transportation, ensure a plentiful and cheap supply of goods through an efficient system of goods distribution are essential. Public health condition can be developed, the efficient and equal distribution of wealth among the society peoples and equal work to equal pay are the essential factors. The Green and Lean Industrial Engineering Manufacturing Procedures will play essential role while strengthening are developing environmental sustainability and making firm financially strong.

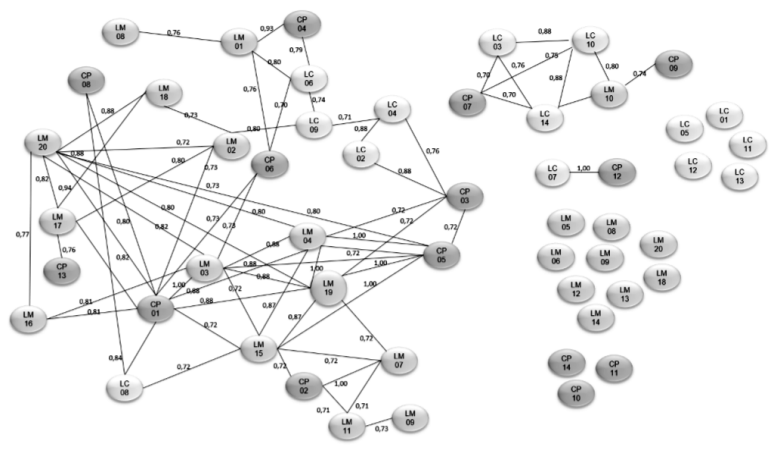

Figure 10: Network of correlation between LM and GM practices [24]

The above Figure 10 witnessed the LI (Lean Initiatives) and GI(Green Initiatives) will have strong correlation with the other factors. The environmental sustainability will show the positive relationship with by reducing air, water and land pollution along with it will show positive relationship with society people health condition. The Lean Industrial manufacturing practices also will show significant positive relationship with the financial viability of the organization. If the organization strictly follows the Lean initiatives: like: minimizing cost, waste and lead time in the production process and successfully applying time study and method study concepts to run organization in an successful manner.

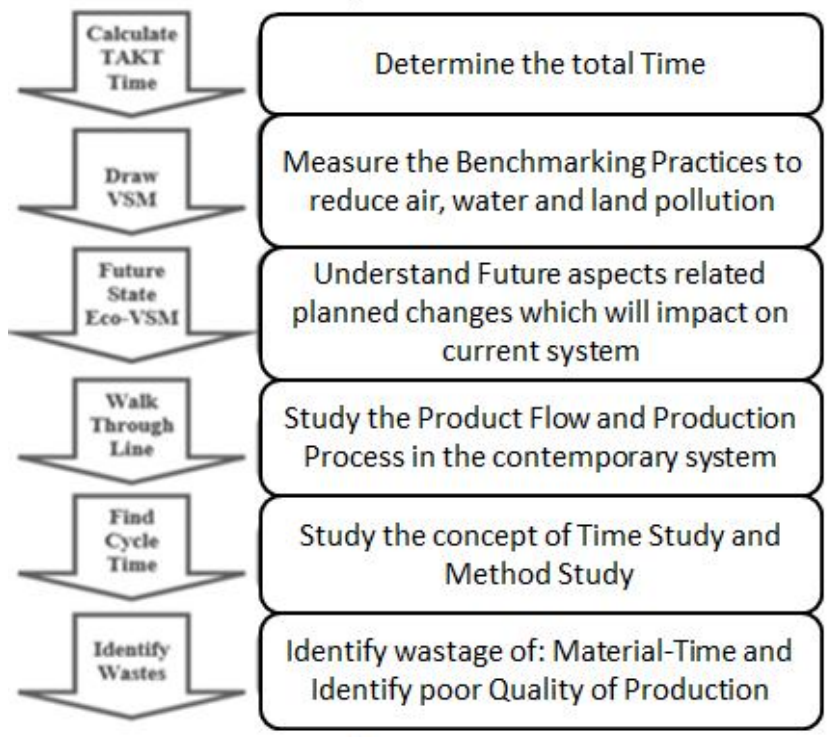

Figure 11: Lean contributions in the production process
The above Figure 11 witnessed that there are certain steps which we need to follow for economic viability of the organization through Lean industrial engineering manufacturing practices. They are applying the concepts of Time Study and Method study: Time study will tell us how much time will be taken to accomplish a particular task, and method study will tell us about, which is the best method to produce a product/service. Need to understand the concept of lean time, need to follow what are the bench marking strategies to minimize wastage of material, unnecessary deployment of human resource, overcome air, water, land pollution and studying the concept of product follow, procedure flow and current production process in the manufacturing unit followed by statistical quality control and inventory control techniques which will facilitates to minimize cost of production ultimately lead to financial viability of the organization.

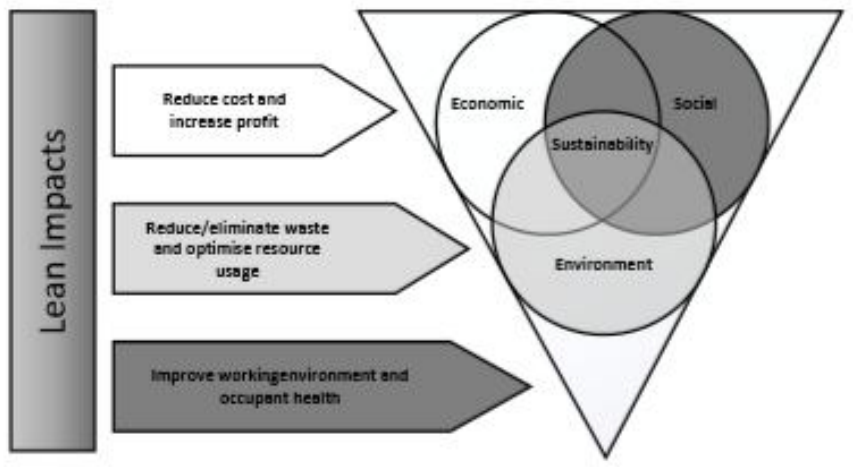

Figure 12: Lean contributions towards sustainability The Figure 12 proves the Lean manufacturing practices will improve the working conditions of the organization followed by reduce cost related to material, time and improving quality of the product. The Lean principles will also facilitate the optimum utilization of existing resources in the production department through the concepts of time study and method study. Therefore, it can be evident that, the both Green and Lean initiatives will show the significant impact on financial aspects of the organization along with the environmental sustainability. The further research will be continued through the primary and secondary data sources.

\section{RESEARCH METHODOLOGY AND DESIN}

The research study is all about descriptive research design. Researcher has taken major advantage from secondary data sources followed by primary data sources.

1. Data sources: Used both primary and secondary data sources for data collected from various respondents.

2. Sampling Frame: The selected manufacturing units in Andhra Pradesh will be considered for research study.

3. Sampling Technique: Simple Random sampling technique was adopted to collect the data from various respondents.

4. Statistical Tools: Applied confirmatory factor analysis to identify various factors involved in the study. Need to identify various factors exist in Green and Lean Manufacturing procedures. 
5. Objectives: The basic objective or purpose or aim of the research study was to know the impact of Green and Lean manufacturing practices followed by the various companies and its impact on environmental sustainability and strengthening the organization financially strong.

6. Need/Importance of the Study: In the contemporary world there is a huge need to protect the environment free from all sorts of hazards in the society and need to protect the resources for future generation and need to avoid all sorts of pollution like: air, water and land pollution.

7. Statement of the Problem: The impact of Green and Lean Industrial Engineering Manufacturing Practices followed in the selected companies in Andhra Pradesh.

8. Scope of the Study: The present study cannot be generalized to all parts of the country; it is restricted to only the present study area.

9. Hypothesis of the study: Researcher is tried to apply Null hypothesis to test the relationship among the variables.

$H_{0}(1)$ : There is no significant relationship between Green industrial engineering manufacturing practices with respect to environmental sustainability in the study area.

$H_{0}(2)$ : There is no significant relationship between Lean Industrial engineering manufacturing practices with respect to financial performance of the organization.

10. Limitations of the Study:- The major limitation of the study is related to scope. The outcome of the research cannot be generalized to all parts of the country.

\section{RESULTS AND DISCUSSIONS}

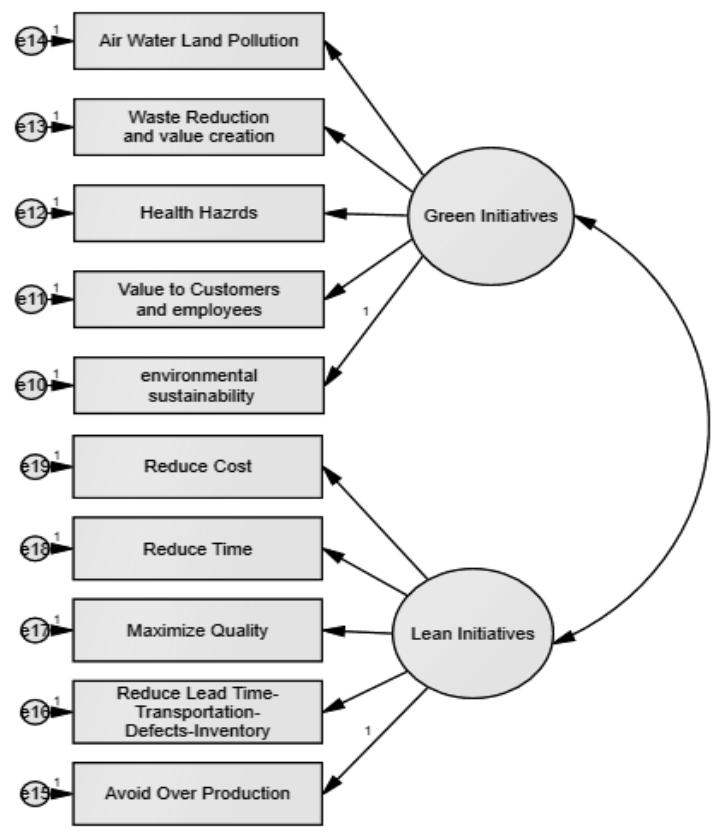

Figure 13: Conceptual Model
The conceptual model Figure 13 explains about, the Green and Lean Manufacturing processes in the industries. The green practices include: to overcome Air, water, land pollution, waste reduction and value creation, health hazards overcome, value creation of employees and customers and environmental sustainability. The lean practices include reduce manufacturing cost, reduce lead time of manufacturing, maximize quality, reduce transportation cost, reduce defects in production and reduce inventory cost and avoid over production. The Green and Lean manufacturing procedures are essential for environmental sustainability along with financial growth of the organization. But, some studies provide that, both were complement to each other. When we concentrate on green principles to develop the organization, it will become tough to implement lean procedures will leads to less economic performance of the organization. The Green and Lean principles will have significant impact to develop organization environmental sustainability along with the financial growth of the organization.

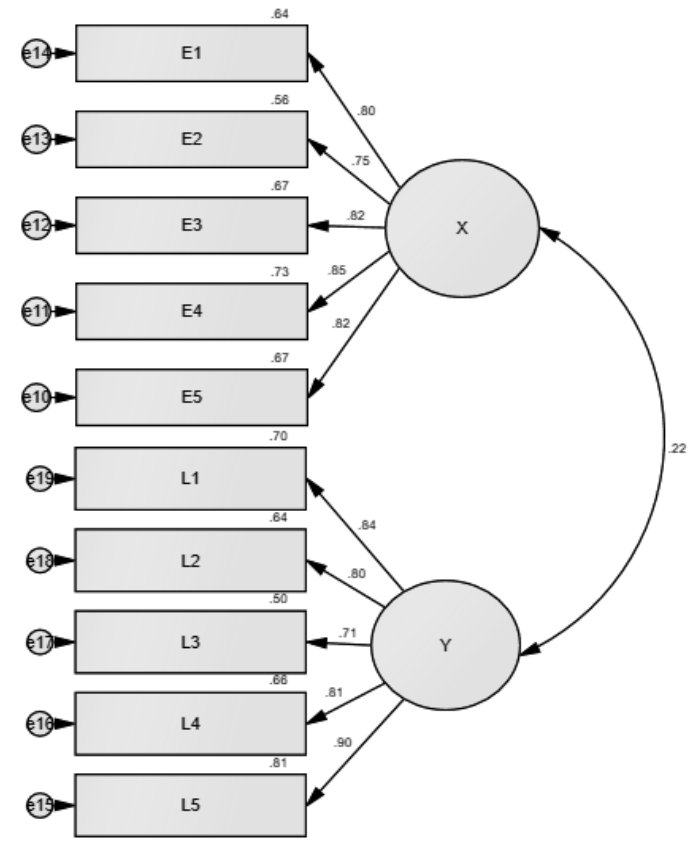

Figure 14: Conceptual Model Analysis

The Figure 14 proves the Model has shown good fit with, GFI $>.90$, AGFI $>090$, TLI $>.90$, Chi-Square <5, RMSEA<.08. The model related factors validated done through confirmatory factor analysis which has proved that all variables were loaded $>0.70$ which shows that, the model fit and confirmatory factor analysis was strongly recommended for above analysis. Here in this model the loaded all variables shows more than 0.50 values, which proved that the model was developed with a good fit (Fornell and Larker, 1981, p.46). The correlation among the variables which shows the relationship between the variables in the analysis. The Model Fit values also shown that, GFI=.965 followed by AGFI= 0.943 , RMSEA was 0.055 which is less than 0.08 , CFI $>0.984$ gives the good fit for model. Interaction Plots: The interaction plot reveals that, the financial performance of an organization depends up on minimizing the cost, time and 
wastage which depends up on the lean practices followed by the organization. If the organization successfully implements the Lean practices, the financial performance of the organization will be enhanced. Apart from this, the financial performance can be enhanced through maximizing quality by applying Lean industrial Manufacturing practices in the selected companies. The lean practices of an organization can be strengthened with the help of time and method study. The time study will explains about how much time will be taken to manufacture a particular product and method study will explains about which is the best method to produce a product all are the essential elements.

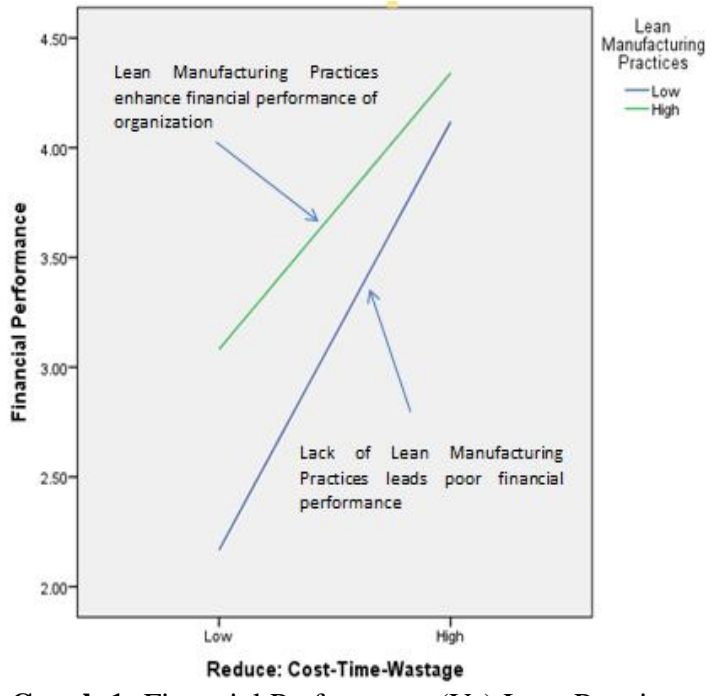

Graph 1: Financial Performance (Vs) Lean Practices

From the above graph 1 it is reveals that, financial performance can be enhanced through applying Lean Manufacturing practices which minimizes (cost of production, reduce wastage, minimize lead time and maximize production).The organizational objectives can be reached through successfully applying Lean manufacturing practices in the manufacturing concern. All these factors are essential to strengthen the organization economically strong. Followed by maniximing quality of the product is also essential to strengthen the economic position of the organization. The following table explains about how Lean production practices will influence the financial aspects of the organization.

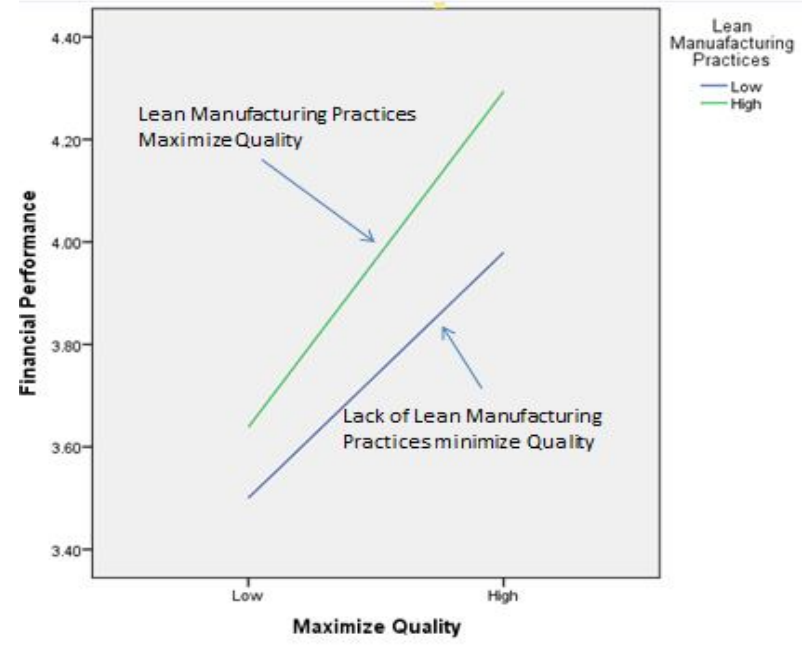

Graph 2: Financial Performance (Vs) Lean Practices
The above Graph 2 reveals the Lean Manufacturing practices will strengthen the financial position of the company by maximizing quality of the product, minimizing price, reducing wastage of material and even minimizing the lead time in production process also will assist to maximize the revenue to the organization. All these things are essential to maximize profits in the organization. Apart from this certain Green Industrial engineering manufacturing practices also essential to strengthen or to gain the environmental sustainability which include preventing air, water and land pollution which create good health to society people and which create value to customers and society in the contemporary business scenario.

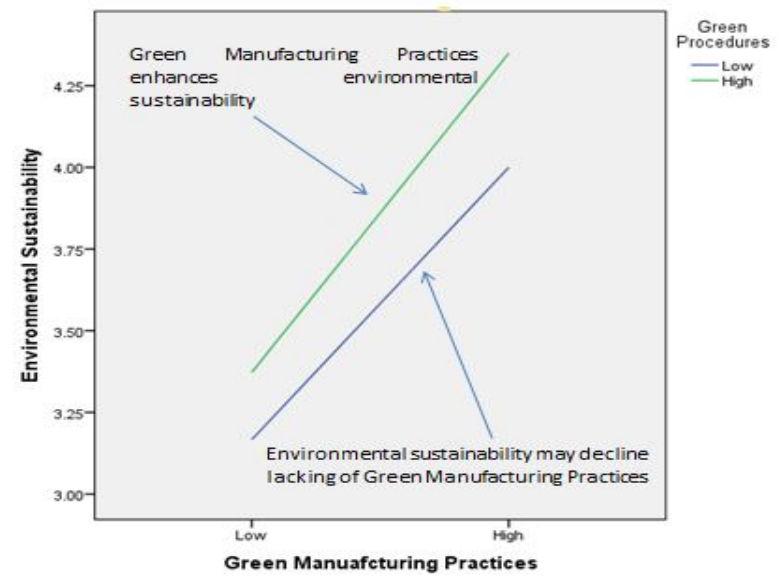

Graph 3: Environmental Sustainability (Vs) Green Practices The above Graph 3 proves, green manufacturing practices are essential to protect Environmental sustainability and to enhance the value streamline to the customers and employees. The both Green and Lean manufacturing practices which plays a significant role to develop the nation to meet the objective of environmental sustainability along with to develop organizational financial performance. Further the Graph 4 also proved the same outcome: the value mapping model will strengthen environmental sustainability where green manufacturing practices are the major philosophies in Green and Lean Industrial Manufacturing Practices in the selected study area. Hence, it can be proved that the Green and Lean Industrial manufacturing practices will helps to strengthen the industrial economy and organizational profitability.

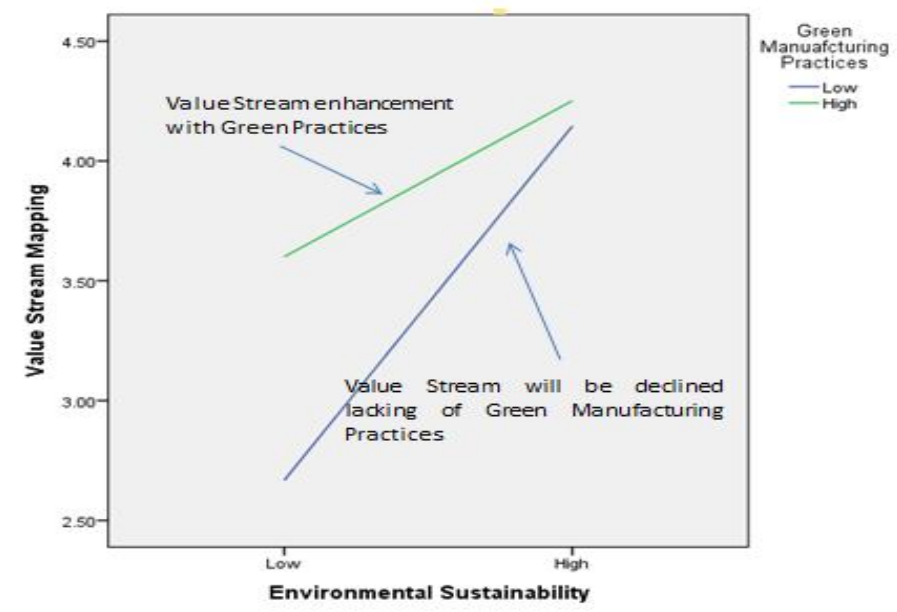

Graph 4: Environmental Sustainability (Vs) Value stream mapping 


\section{FINDINGS}

1. The Green Industrial Engineering manufacturing practices like: prevention of air, water, and land pollution have shown the significant positive relationship with the environmental sustainability.

2. The Lean Industrial Engineering manufacturing practices like: Times study and method study include (reducing wastage of time, material, cost and maximizing quality) have shown the positive impact with the financial growth of the organization.

3. The Null hypothesis rejected and accepted alternative hypothesis i.e., there is a significant positive relationship with environmental sustainability with the controlling pollution of air, water and land along with can control/prevent health problems related to the employee concern.

4. The Null hypothesis rejected related to the Lean industrial engineering manufacturing practices with respect to financial performance of the organization. The financial performance of the organization will have positive impact with respect to minimizing of wastage of material, time, cost and maximizing the quality of the product.

5. In the all aspects the both Green and Lean manufacturing practices have shown the significant positive impact on environmental sustainability and organizational growth.

6. The interaction plots have shown the significant changes with respect to environmental sustainability and with respect to implementation of green practices and Lean practices in study area.

7. All the variables under Green and Lean manufacturing practices have shown the positive relationship with the variables. Therefore, it can be conclude that the all Green and Lean Manufacturing procedures have shown the significant positive relationship with strengthening environmental sustainability and financial performance of the organization.

\section{CONCLUSION}

Therefore, it can be conclude that the both Green and Lean manufacturing practices have shown the significant relationship with the environmental sustainability and organizational development. It is must to develop nation in all aspects and need to show better path for future generation. Now in the contemporary world lacking of hygienic practices numerous pandemics are coming in to the world, creating many problems of the survival of the society. In this context, it is mandatory to develop nation in all like: protecting the environment from pollution free which include air, water and land pollution followed by strengthening the organization economic viability by applying Lean manufacturing practices like: reducing cost of manufacturing, reducing wastage and maximizing quality of the product. In fact, there are numerous manufacturing technologies also available to go for green industrial manufacturing practices, especially the plastic recycling and waste material processing plants are playing significant role to maintain environmental sustainability in the contemporary business world.

\section{CONFLICT OF INTEREST}

With the all authors mutual consent sent this paper for publication in the esteemed journal. All the authors are haven mutual agreement regarding content included in the article. All authors made significant contribution to conduct the study in the area of Green and Lean Industrial Manufacturing Units in Andhra Pradesh.

\section{SOURCES OF FUNDING}

We have not received any state and central financial assistance to run research in the specified area. There is no financial support from any agency to perform this research work. The research as done purely with the efforts of authors.

\section{ACKNOLEDGEMENT}

We respect the suggestions and modifications of the esteemed editorial board members to strengthen the quality of the research work which we have done at present. We would like to thank to all editorial board members, reviewers and higher officials concern to this journal.

\section{REFERENCES}

1. A.M. Deif, "A system model for Green manufacturing," Journal of Cleaner Production, vol. 19, no. 14, pp. 1553-1559, 2011. https://doi.org/10.1016/j.jclepro.2011.05.022

2. R. Shah and P.T Ward, "Lean manufacturing: context, practice bundles, and performance," Journal of operations management, vol. 21, no. 2, pp. 129-149, 2003.

3. Dieste, M.; Panizzolo, R. On the Relationship between Lean Practices and Environmental Performance. In Proceedings of the IOP Conference Series: Earth and Environmental Science; IOP Publishing: Bristol, UK, 2018; Volume 151.

4. Garza-Reyes, J.A. Green lean and the need for Six Sigma. Int. J. Lean Six Sigma 2015, 6, 226-248. https://doi.org/10.1108/IJLSS-04-2014-0010

5. Marhani,M.A.;Jaapar,A.;Bari,N.A.A.;Zawawi,M.Sustai nabilityThroughLeanConstructionApproach: Literature Review. Procedia Soc. Behav. Sci. 2013, 101, 90-99 https://doi.org/10.1016/j.sbspro.2013.07.182

6. Gehin, A.; Zwolin'ski, P.; Brissaud, D. A tool to implement sustainable end-of-life strategies in the product development phase. J. Clean. Prod. 2008, 16, 566-576.

7. Bortolotti, T.; Boscari, S.; Danese, P. Successful lean implementation: Organizational culture and soft lean practices. Int. J. Prod. Econ. 2015, 160, 182-201. https://doi.org/10.1016/j.ijpe.2014.10.013

8. Wagner, M.; Van Phu, N.; Wehrmeyer, W. The relationship between the environmental and economic performance of firms: An empirical analysis of the European paper industry. Corp. Soc. Responsib. Environ. Manag. 2002, 9, 133-146. 
9. Vogel, D. Trading Up: Consumer and Environmental Regulation in a Global Economy; Harvard University Press: Cambridge, UK, 2009.

10. Cherrafi, A.; ElFezazi, S.; Govindan, K.; Garza-Reyes, J.A.; Benhida, K.; Mokhlis, A. A framework for the integration of Green and Lean Six Sigma for superior sustainability performance. Int. J.Prod. Res. 2016, 55, $4481-4515$

https://doi.org/10.1080/00207543.2016.1266406

11. Choudhary, S.; Nayak, R.; Dora, M.; Mishra, N.; Ghadge, A. An integrated lean and green approach for improving sustainability performance: A case study of a packaging manufacturing SME in the UK. Prod. Plan. Control. 2019, 30, 353-368.

12. Xu,X.S.;Walker,H.;Nairn,A.;Johnsen,T.Anetworkappro achtounderstanding 'greenbuying': A literature review. Presented at the 23rd IMP Conference, Manchester, UK, 30 August-1 September 2007.

13. Mollenkopf,D.;Stolze,H.;Tate,W.L.;Ueltschy,M.Green,I ean,andglobalsupplychains. Int. J.Phys. Distrib. Logist. Manag. 2010, 40, 14-41.

14. Sundar, R.; Balaji, A.N.; Kumar, R.S. A Review on Lean Manufacturing Implementation Techniques. Procedia Eng. 2014, 97, 1875-1885.

15. P.J. Martínez-Jurado and J. Moyano-Fuentes, "Lean management, supply chain management and sustainability: a literature review", Journal of Cleaner Production, vol. 85, pp. 134-150, 2014.

16. S. Rothenberg, F.K. Pil and J. Maxwell, "Lean, Green, and the quest for superior environmental performance", Production and Operations Management, vol. 10, no. 3, pp. 228-243, 2001.

17. Verrier, Brunilde, et al. Combining organizational performance with sustainable development issues: the 768

18. Yogesh P. Deshmukh and Dr. Atul B. Borade (2019). Performance evaluation of the Indian plastic processors supply chain: Implementing lean and green philosophies. International Journal of Emerging Trends in Engineering Research, Vol.7 (5), 2019.

https://doi.org/10.30534/ijeter/2019/01752019

19. Aymen Awad (2020). Guidelines for Civil Structures Demolition Method Selection to Enhance Environmental Protection. International Journal of Emerging Trends in Engineering Research, Vol.8 (2), 2020.

https://doi.org/10.30534/ijeter/2020/11822020

20. B. Sezen and S.Y. Cankaya, "Effects of Green manufacturing and Eco innovation on sustainability performance", Procedia-Social and Behavioral Sciences, vol. 99, pp. 154-163, 2013.

21. C.A. Rusinko, "Green manufacturing: an evaluation of environmentally sustainable manufacturing practices and their impact on competitive outcomes", Engineering Management, IEEE Transactions on, vol. 54, no. 3, pp. 445-454, 2007. https://doi.org/10.1109/TEM.2007.900806

22. Jawahir, I.S., Wanigarathne, P. C., and Wang, X. (2006). In Kutz, M (Ed), Mechanical Engineers' Handbook:
Manufacturing and Management. (414-443). New York: John Wiley \& Sons, Inc. https://doi.org/10.1002/0471777463.ch12

23. DETR. Sustainable Distribution: A Strategy. Office of the Deputy Prime Minister (ODPM), UK, March 1999.

24. Proceedings of the International Conference on Industrial Engineering and Operations Management Pilsen, Czech Republic, July 23-26, 2019. 